\title{
E-Recruitment in Practice: A Study on Jobseekers' Perception in Bangladesh
}

\author{
Mohammad Rezaul Karim ${ }^{1}$, Md. Shelim Miah ${ }^{2 *}$, Asma Khatun ${ }^{3}$
}

${ }^{1}$ Assistant Professor, Department of Business Administration, Shanto-Mariam University of Creative Technology (SMUCT), Dhaka-1230, BANGLADESH

${ }^{2}$ Assistant Professor, Department of Business Administration, Asian University of Bangladesh, Dhaka-1230, BANGLADESH

${ }^{3}$ Lecturer, Department of Business Administration, Asian University of Bangladesh, Dhaka-1230, BANGLADESH

*Corresponding Contact:

Email: transitory63@gmail.com

Cell Phone: +8801818290760

\begin{abstract}
The rapid growth and use of the Internet over the last several years has changed the way companies' conduct of business activities, including the activities of human resource management. To attract and recruit best employees is one of the great challenges for Human Resource Department. Today online recruiting has become a significant tool for Human Resource Department. Bangladeshi companies also can recruit with their websites, job boards or resume banks, newspaper classified ads, and job boards. Online recruiting processes increase firms' competitive advantage through increased efficiency and lower costs and offers benefits and opportunities to jobseekers. This paper investigates the perceptions and behaviors of job-seekers concerning the use of the Internet as a recruiting source. 204 survey questionnaires were distributed to job seekers who are almost regularly using Internet for various purposes. The results showed that perceived usefulness and perceived enjoyment are positively and significantly related to the behavioral intention to use Internet as a job search tool. The study implies that the developers of online job sites need to provide additional useful functionalities or tools in the sites to help users for job search. The paper provides an insight for jobseekers to find employment by using Internet as a job search tool.
\end{abstract}

Keyword: e-recruiting, evaluation, Internet job market, Internet job boards, Internet job sites, online recruiting

\section{INTRODUCTION}

In the contemporary impulsive business, one of the most distinctive competitive advantages companies can gain and sustain is their human resources. Thomas and Ray, (2000) believe that the single most important determinant of organizational effectiveness is the ability to attract, hire, and develop capable talent. To be able to compete, firms must be able to find and retain the best available employees, is difficult due to the shrinking availability of qualified labor. Furthermore, the rise of computer technology and the Internet has changed 
the way businesses compete. One area that has been changed drastically by information technology is e-recruiting or online recruitment. As the doors of Internet access are opened to more people and as the digital divide shrinks through less expensive computers, Internet service providers, Internet appliances and other Internet access devices, Internet recruitment for many types of jobs and positions across many industries have the potential for increased application and growth.

Mandy and Noe (2008) state that recruitment is the process of identifying and attracting potential employees, whereas selection is the process of making decisions to select these employees though recruitment is considered the critical part of organizational human resource development. E-recruitment is a means of using information technology (IT) to perform, speed up or improves this process (Tong and Sivanand, 2005), E-recruitment also falls under e-HRM which is an organization's e-business system that uses web-based technologies for human resource management practices and policies (Ruel et al. 2007). E-HRM system and its subsystems, such as e-recruitment, produce a higher level of service delivery and a better strategic contribution. E-recruitment emerges as a handy and advantageous method over traditional methods of recruitment as it brings all benefits of e-business into the human resource field and improves the efficiencies of the recruitment process.

In Bangladesh, the number of internet subscribers is increasing at a high speed; the total number of Internet Subscribers has reached 37172.05 thousand at the end of April, 2014. (www.btrc.gov.bd/telco/internet). The connectivity through the internet is being served various purposes, including the e-recruiting. So, the scope of online recruiting is expanding. At the beginning, e-recruitment system was use by private sector, like various MNCs, private banks, NGOs but at present this system is followed by both private and public sectors. Today the PSC, the largest recruiting authority for public sectors also follow the online recruitment system. The use of online recruiting impacts significantly businesses as well as jobseekers who utilize this method in the hiring and job search process. Specially, job-seekers are finding many favorable reasons to use online recruiting including increasing scope, lowering searching costs, secured system, sometime interactive relation with employers, getting more information and simplifying the entire processing intern. But searching jobs by using internet also have some predicaments. So, the direct or indirect internet users have positive as well as negative attitudes towards e-recruitment.

\section{OBJectives OF THE Study}

The broad objective of this study was to analyze the overall attitude of jobseekers' towards the online system of seeking jobs. The specific objectives of this study were to:

- To identify the present condition of seeking job through internet.

- To find out the performance expectancy of the internet for the searching job in Bangladesh.

- To identify jobseeker's competency of seeking job through internet.

- To identify jobseeker's habit of using internet.

- To investigate the expenses and trustworthiness of internet to the job-seeker.

\section{E-RECRUITMENT}

In the era of globalization, anyone who wants to be interested in the corporate world is aware of job-sites. Using internet prospective applicants could search for positions in which they were interested. Contact with employers directly is viable. Feasibility of email overruled the use of telephone, fax or mail, and the companies started accepting application through email. Today Organizations have their sites or job postings are given in the placement sites. Again the candidates can visit the sites, post resume, and contact the 
company directly without any delay. All these are just one 'click' away. E-recruitment is a tool for many employers to search for job candidates and for applicants to look for the job. The Recent trend of recruitment is e-recruitment or the internet recruitment or on-line recruitment, where the process of recruitment is automated.

\section{Methods of e-recruitment}

Methods of e-recruitment are many, among those the important ones are:

- Job Boards: Job boards are the places where the employers post jobs and search for candidates. Candidates become aware of the vacancies. One of the disadvantages is it is generic in nature.

- Company Websites: These sites can be of the company owned sites, or a site developed by various employers. For an example, Directemployers.com is the first cooperative, employerowned e-recruiting consortium formed by Direct Employers Association.

- Professional Websites: These are for specific professions, skills and not general in nature. For an example, for HR jobs Human Resource Management sites to be visited like www.shrm.org. The professional associations will have their site or society.

\section{Advantages of E-recruitment}

- Cost Efficient: Advertisements in internet when compared to newspaper, magazines, and employment agencies is considerably cheap. As in the other sources continuously one has to revise, for example a company wanted their ad to appear on every Sunday for a month thus was supposed to pay for four advertisements. But for internet it is not applicable.

- $\quad$ Time Saving Device: Time to deliver; to communicate is minimized by this. Response is direct and immediate without any delay. Beforehand the postal services, fax was one-way communication and was time consuming. Phones provided two-way communications but resume management, communicating worldwide were not possible.

- Widens the Search: In the era of internet the reach cannot be restricted in one place. It provides global reach that also within a fraction of second. Truly the process supports the definition of recruitment by creating a vast pool of potential candidates.

- Provides Clarity: Advertisements in employment news, other newspapers, and magazines will have word limit, thus sometimes is misinterpreted. For an example a company advertisement announced vacancy for computer person which was interpreted as MIS job which was rather a job for computer skilled receptionist. The advertisement was not clear enough to explain the full profile. In internet the word limitation is not there, the idea, opinion, profile can be expressed as anyone like.

- Scope for Better Match: Information in detail is provided with clarity therefore suitable candidate match is possible. The search is widened link with other websites are possible, these attracts the candidates and after the job profile matches, the candidates apply.

- Standardization: The information of the candidates is collected in a standard format. Besides collecting the data, it also consolidates the information received from various sources.

- $\quad$ Reservoir: It acts as the reservoir of information, from the job profile to candidate profile is available along with past applicant data.

- Reduce Paper Work: As the data collection, filing, administrative work are done electronically thus paper work or documentation has been lessened. 


\section{Disadvantages of E-recruitment}

- Require Being Computer Savvy: The process is restricted only for computer savvy candidates. As the search is based on various websites, their screening, keywords application demands for a computer savvy person and company.

- Legal Consequences: Alike other recruitment sources this source also should be aware of the words used in the advertisements otherwise it may lead to the charge of discrimination. For example, Disney World was sued for screening the resumes preferring the keywords used by whites.

- Vast Pool of Applicants: This benefits the organizations as well as it is disadvantage to them also. Because, the huge database cannot be scanned swiftly in depth. Either first few candidates are called for interview or the resumes are screened based on some key words.

- Non-serious Applicants: Lot of applicants forward their resumes just to know their market value. As personally the candidates are not checked thus whether they are serious or not serious is not known. At the time of interview the recruiter might realize that the candidate is not serious in leaving the current job. But by that time some serious candidates might have been rejected.

- Disclosure of Information: Candidates profile and company details are available to public. The applicants do not want their employer to know that they are looking for a change. Phone number, address information has lead to many security problems.

From the review of related literature regarding jobseeker's perception, the following pertinent issues emerge:

- With the internet, all types of jobs and employees could be easily found and acquired to fill needs (Jansen, B.J., Jansen, K.J., and Spink, A. 2005).

- The Internet recruitment improves corporate image, reduces recruitment cost, reduces administrative burden and employs better tools for the recruitment team (Kerrin M., 2005).

- Internet can assist employees in finding employment opportunities faster and easier than ever before.

- Web-sites are viewed as a very effective recruitment method and are perceived as generating a large number of job applicants at relatively low cost (Stone, D. L., Lukaszewski, K., \& Isenhour, L. C. 2005).

- With the introduction of the internet, the recruitment process has become easier.

- Complexity and the dynamic nature of recruitment practices require continuous updating of knowledge, skills, and abilities.

- Recruitment practices differ in different organizations classified based on organization type, size etc.

- Better recruitment practices have impact on the image of the organization and ability to fill the vacancies more promptly.

\section{Methodology OF THE StUdy}

An empirical study was carried out, using a questionnaire, which were used for this study of a closeended type and includes 25 questions. Some responses are based on five value Likert scale to indicate attitudinal aspects of job-seekers toward e-recruitment systems, and the remaining are simple multiple choice questions that have been organized into a three-page questionnaire. The responses of the sampled jobseeker were evaluated using SPSS software and a set of variables were identified and evaluated to form a statistical picture of the responses to the questionnaire. The sampling method in choosing the participants for this study was a simple random sample. In addition, in this study, samples of 204 job-seekers were selected across the country. 


\section{DATA ANALYSIS AND FINDINGS}

Model Summary

\begin{tabular}{|l|l|l|l|l|}
\hline Model & $\mathrm{R}$ & $\mathrm{R}$ Square & Adjusted R Square & Std. Error of the Estimate \\
\hline 1 & $.008(\mathrm{a})$ & .000 & -.005 & .633 \\
\hline
\end{tabular}

a Predictors: (Constant), Internet Understanding

\section{ANOVA(b)}

\begin{tabular}{|l|l|l|l|l|l|l|}
\hline \multicolumn{2}{|l|}{ Model } & Sum of Squares & $\mathrm{df}$ & Mean Square & $\mathrm{F}$ & Sig. \\
\hline \multirow{3}{*}{1} & Regression & .005 & 1 & .005 & .013 & $.908(\mathrm{a})$ \\
\cline { 2 - 7 } & Residual & 80.951 & 202 & .401 & & \\
\cline { 2 - 7 } & Total & 80.956 & 203 & & & \\
\hline
\end{tabular}

a Predictors: (Constant), Internet Understanding

b Dependent Variable: Education

\section{Coefficients (a)}

\begin{tabular}{|l|l|l|l|l|l|l|}
\hline \multirow{2}{*}{ Model } & & \multicolumn{2}{|l|}{$\begin{array}{l}\text { Unstandardized } \\
\text { Coefficients }\end{array}$} & $\begin{array}{l}\text { Standardized } \\
\text { Coefficients }\end{array}$ & $\mathrm{t}$ & Sig. \\
\hline & & B & Std. Error & Beta & & \\
\hline 1 & (Constant) & 2.539 & .214 & & 11.885 & .000 \\
\hline & Internet Understanding & -.006 & .055 & -.008 & -.116 & .908 \\
\hline
\end{tabular}

a Dependent Variable: Education

The above analysis shows the relation between education level and Internet understanding. The Result shows that the significance is very high, so there is no relation between education level and Internet understanding.

\section{Case Processing Summary}

\begin{tabular}{|l|l|}
\hline & N \\
\hline Total Cases & 204 \\
\hline Excluded Cases(a) & 0 \\
\hline Forecasted Cases & 0 \\
\hline Newly Created Cases & 0 \\
\hline
\end{tabular}

a Cases with a missing value in any variable are excluded from the analysis.

\section{Variable Processing Summary}

\begin{tabular}{|c|c|c|c|}
\hline & \multicolumn{2}{|l|}{ Variables } \\
\hline & & Dependent & Independent \\
\hline & & Job Area & Response rate \\
\hline \multicolumn{2}{|l|}{ Number of Positive Values } & 204 & 204 \\
\hline \multicolumn{2}{|l|}{ Number of Zeros } & 0 & 0 \\
\hline \multicolumn{2}{|l|}{ Number of Negative Values } & 0 & 0 \\
\hline \multirow[t]{2}{*}{ Number of Missing Values } & User-Missing & 0 & 0 \\
\hline & System-Missing & 0 & 0 \\
\hline
\end{tabular}




\section{Model Summary and Parameter Estimates}

Dependent Variable: Job Area

\begin{tabular}{|l|l|l|l|l|l|l|l|}
\hline Equation & \multicolumn{4}{l|}{ Model Summary } & \multicolumn{2}{l|}{ Parameter Estimates } \\
\hline & R Square & $\mathrm{F}$ & $\mathrm{df1}$ & $\mathrm{df} 2$ & Sig. & Constant & b1 \\
\hline Linear & .001 & .112 & 1 & 202 & .739 & 3.079 & .040 \\
\hline
\end{tabular}

The independent variable is Response rate.

Job Area
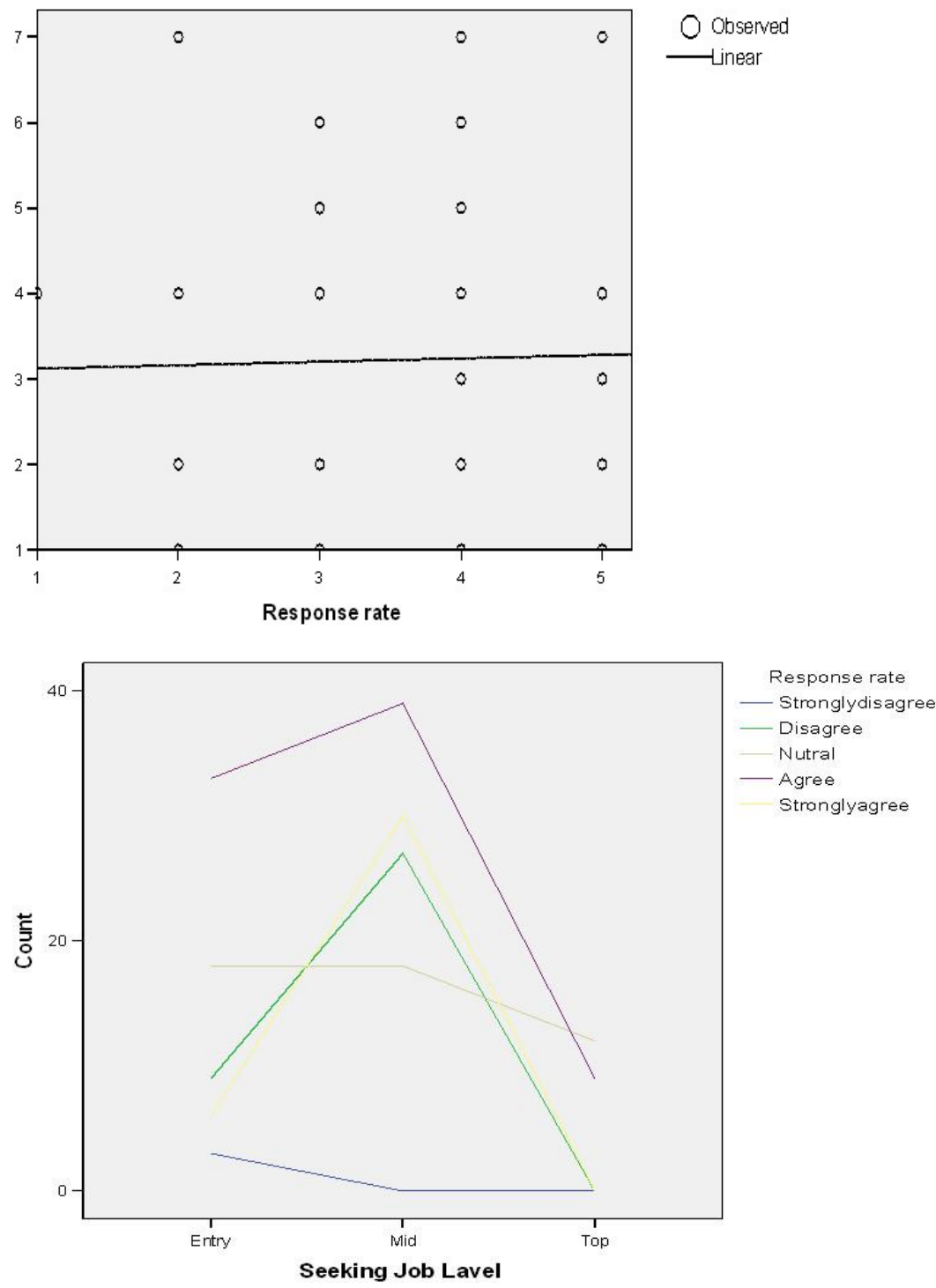

The above diagram shows that job-seekers of both mid-level and entry-level using Internet much. Moreover, entry-level job-seekers use Internet more that the mid-level jobseekers. 


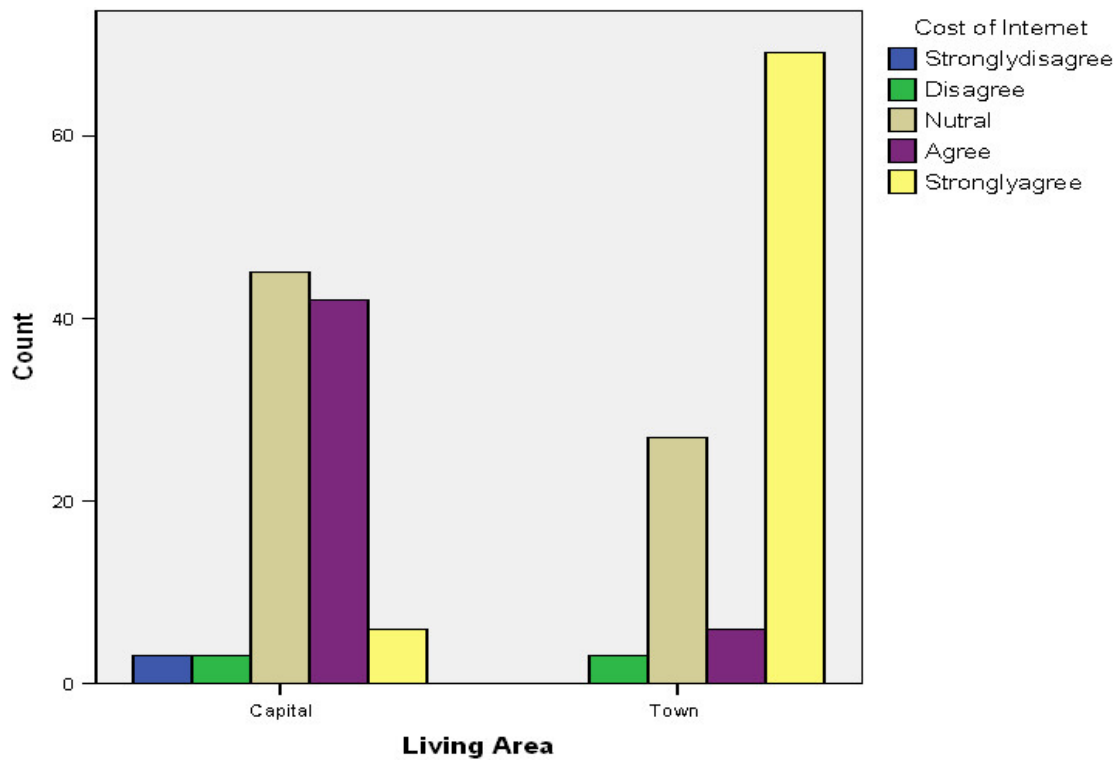

The above diagram shows the relation between the cost of internet service and living area. Here, most of the jobseekers live in the capital city think the cost of Internet is reasonable whereas the respondents in town (not the capital city) think the cost of the Internet is very costly.

\section{CONCLUSION}

The Internet has had a good impact on the way companies recruiting employees. Erecruiting system is newly invented and sharply growing but traditional ways of recruiting, through newspapers or employee referral, have not become obsolete. There is no doubt that the number of Internet users in Bangladesh is increasing still its penetration is low, in most of the cases they use Internet for limited purposes. Therefore, studying internet recruitment is very significant in order to maximize its financial and non-financial benefits for both employers and job-seekers. In this study, it was found that the use of the Internet for jobseeking is influenced positively. Intentions to use the Internet for job-seeking are influenced by WWW usage habits and performance expectancy of the internet services. The findings of the reveals that the response rate from the employers is comparatively low, the jobseekers sometimes become disappointed. So, searching job through Internet is becoming very popular but prevailing drawbacks should be eradicated by the interested stakeholders.

\section{REFERENCES}

Ahmed, A., \& Siddique, M. (2013). Internet Banking Espousal in Bangladesh: A Probing Study. Engineering International, 1(2), 40-47.

Ahmed, M. (2014). Effects of Interpersonal Problems at Workplace on Job Involvement. Global Disclosure Of Economics And Business, 1(1), 44-53.

Ahmed, M. (2015). The Role of Self-esteem and Optimism in Job Satisfaction among Teachers of Private Universities in Bangladesh. Asian Business Review, 1(2), 114-120.

Akhter, M., Siddique, N., \& Alam, A. (2014). HRM Practices and its Impact on Employee Performance: A Study of the Cement Industry in Bangladesh. Global Disclosure Of Economics And Business, 2(2), 125-132.

Aktar, S., Islam, M., \& Hossen, S. (2015). Human Resource Management Practices and Firms Performance in Bangladesh: An Empirical Study on Pharmaceutical Industry. Asian Business Review, 1(2), 121-125. 
Alam, S. (2015). Factors Affecting Job Satisfaction, Motivation and Turnover Rate of Medical Promotion Officer (MPO) in Pharmaceutical Industry: A Study Based in Khulna City. Asian Business Review, 1(2), 126-131.

G.D.N., P., Khatibi, ., \& Navaratna, N. (2014). Employee-organization Congruence and Job Performance: Development of a Conceptual Model. Global Disclosure Of Economics And Business, 2(2), 116-124.

Hossain, M., \& Siddique, T. (2015). Career Preference of Business Graduate in Bangladesh: A Case Study of Some Selected Private Universities. Asian Business Review, 1(2), 106-113.

Jansen, B.J., Jansen, K.J., and Spink, A. (2005), “ Using the Web to Look for Work- Implications for Online Job Seeking and Recruiting Internet Research" Journal of Internet Research, Vol. 15 No. 1, pp. 49-66

Kerrin M. (2005), "E-Based Recruitment: New Challenges in the Application of Selection and Assessment", Paper presented at the Division of Occupational Psychology Conference,Warwickshire, UK.

Mondy, R.W., And Noe, R.M., (2008), Human Resource Management, $10^{\text {th }}$ Edition, New Jersey, Prentice-Hall

Nasima, M., \& Alam, N. (2015). Job Satisfaction among Female Fculties of Different Public and Private Universities in Bangladesh: A Comparative Analysis. ABC Journal Of Advanced Research, 4(1), 16-26.

Rahman, M., \& Islam, M. (2012). An Analytical Study on Determining Effective Factors for Recruiting Right Person. ABC Journal Of Advanced Research, 1(2), 50-56.

Ruel, H., Bondarouk, T. V. \& Van Der Velde, M. (200 7) The Contribution Of E-HR M To HRM Effectiveness: Results From A Quantitative Study In A Dutch Ministry, Employee Relations, 29, 3, 280-291.

Stone, D. L., Lukaszewski, K., \& Isenhour, L. C. (2005), "e-Recruiting: Online Strategies for Attracting Talent", In H. Gueutal \& D. L. Stone (Eds.), The Brave New World of EHR: Human Resourcesin the Digital Age (pp. 22-53). New York: John Wiley \& Sons

Thomas, S.L., \& Ray, K. (2000). Recruiting and the web: high-tech hiring. Business Horizons, 43, 43-53. Retrieved May 17, 2005, from EBSCOhost database.

Tong, T.Y.K., and Sivanad, C.N., (2005), e-recruitment service provider review, Employee Relations, Volume: 27 Number: 1 ,Year: 2005, pp:103-117).

Tsegaye, M., \& Moges, B. (2014). Roles And Challenges of Secondary School Instructional Leadership for the Achievement of Student Learning: The Case of South Gondar Administrative Zone, Amhara Region, Ethiopia. Asian Journal Of Humanity, Art And Literature, 1(1), 48-69.

www.btrc.gov.bd/telco/internet. 


\section{APPENDIX}

Jobseeker's Perception/Attitude on E-recruitment in Bangladesh

Name:

Cell:

Mail:

\section{A. Demographic Information:}

1. Gender:

$\square$ male

$\square$ Female

2. Age(Years):

$\square 20-25$

$\square$ 26-35

$\square 36-50$

$\square 50+$

3. Education Qualification: $\square$ SSC- HSC

$\square$ Graduate $\quad \square$ Masters

$\square$ M. Phil/Ph.D

4. Mention your seeking job level:

$\square$ Entry level

$\square$ Mid Level

$\square$ Top Level

5. Where do live in at the moment:
$\square$ Capital/Divisional City
$\square$ District City/ Town
$\square$ Rural Area
6. Status of Employment:
$\square$ Employed
$\square$ Unemployed
7. Sector of Employment:
$\square$ Public
$\square$ Private

8. Professional/ Job Areas:

$\square$ IT Professional $\square$ Marketing

$\square$ Banker
$\square$ Administrator
$\square$ engineering
$\square$ Doctor
$\square$ others

9. Your job Experience(Years): $\square$ 0-3 $\square$ 3-5 $\square 5-10 \quad \square 10+$
10. Income Range(BDT, '000'):
$\square$ No
$\square 5-20$
$\square 20-50$
$\square$ 50-100
$\square 100+$

\section{B. Performance Expectancy:}

11. The Internet is easy to understand:

\begin{tabular}{|c|c|c|c|c|}
\hline $\begin{array}{l}\text { Strongly } \\
\text { Agree }\end{array}$ & Agree & $\begin{array}{l}\text { Neither Agree } \\
\text { nor Disagree }\end{array}$ & Disagree & $\begin{array}{c}\text { Strongly } \\
\text { Disagree }\end{array}$ \\
\hline 5 & 4 & 3 & 2 & 1 \\
\hline
\end{tabular}

12. Internet job-sites are easy to use:

\begin{tabular}{|c|c|c|c|c|}
\hline $\begin{array}{l}\text { Strongly } \\
\text { Agree }\end{array}$ & Agree & $\begin{array}{l}\text { Neither Agree } \\
\text { nor Disagree }\end{array}$ & Disagree & $\begin{array}{l}\text { Strongly } \\
\text { Disagree }\end{array}$ \\
\hline 5 & 4 & 3 & 2 & 1 \\
\hline
\end{tabular}

13. Internet is easy to interact with others:

\begin{tabular}{|c|c|c|c|c|}
\hline $\begin{array}{l}\text { Strongly } \\
\text { Agree }\end{array}$ & Agree & $\begin{array}{l}\text { Neither Agree } \\
\text { nor Disagree }\end{array}$ & Disagree & $\begin{array}{l}\text { Strongly } \\
\text { Disagree }\end{array}$ \\
\hline 5 & 4 & 3 & 2 & 1 \\
\hline
\end{tabular}


14. The information which is given in jobsites is sufficient?

\begin{tabular}{|c|c|c|c|c|}
\hline $\begin{array}{l}\text { Strongly } \\
\text { Agree }\end{array}$ & Agree & $\begin{array}{l}\text { Neither Agree } \\
\text { nor Disagree }\end{array}$ & Disagree & $\begin{array}{l}\text { Strongly } \\
\text { Disagree }\end{array}$ \\
\hline 5 & 4 & 3 & 2 & 1 \\
\hline
\end{tabular}

\section{Facilities Conditions:}

15. Do you have the necessary resources to enable you to access the Internet:

\begin{tabular}{|c|c|c|c|c|}
\hline $\begin{array}{l}\text { Strongly } \\
\text { Agree }\end{array}$ & Agree & $\begin{array}{l}\text { Neither Agree } \\
\text { nor Disagree }\end{array}$ & Disagree & $\begin{array}{l}\text { Strongly } \\
\text { Disagree }\end{array}$ \\
\hline 5 & 4 & 3 & 2 & 1 \\
\hline
\end{tabular}

16. You have the knowledge and training available to learn to use the Internet:

\begin{tabular}{|c|c|c|c|c|}
\hline $\begin{array}{l}\text { Strongly } \\
\text { Agree }\end{array}$ & Agree & $\begin{array}{l}\text { Neither Agree } \\
\text { nor Disagree }\end{array}$ & Disagree & $\begin{array}{l}\text { Strongly } \\
\text { Disagree }\end{array}$ \\
\hline 5 & 4 & 3 & 2 & 1 \\
\hline
\end{tabular}

17. How do you access the Internet? $\square$ Broadband $\square$ Modem $\square$ Mobile

18. . Do you think online job offer always covers your desired level?

\begin{tabular}{|c|c|c|c|c|}
\hline $\begin{array}{l}\text { Strongly } \\
\text { Agree }\end{array}$ & Agree & $\begin{array}{l}\text { Neither Agree } \\
\text { nor Disagree }\end{array}$ & Disagree & $\begin{array}{l}\text { Strongly } \\
\text { Disagree }\end{array}$ \\
\hline 5 & 4 & 3 & 2 & 1 \\
\hline
\end{tabular}

19. Receiving response from employer after submitting online applications:

\begin{tabular}{|c|c|c|c|c|}
\hline $\begin{array}{l}\text { Strongly } \\
\text { Agree }\end{array}$ & Agree & $\begin{array}{l}\text { Neither Agree } \\
\text { nor Disagree }\end{array}$ & Disagree & $\begin{array}{l}\text { Strongly } \\
\text { Disagree }\end{array}$ \\
\hline 5 & 4 & 3 & 2 & 1 \\
\hline
\end{tabular}

D. Habit:

20. How often do you use the Internet: $\square$ Everyday $\square$ Once a week $\square$ Once a fortnight $\square$ Once a Month $\square$ Never

21. How often do you read the Newspaper: $\quad \square$ Everyday $\square$ Once a week

$\square$ Once a fortnight $\square$ Once a Month $\square$ Never

22. Have you personal Internet Connection? $\square$ Yes $\square$ No $\square$ No comment

E. Trust, Cost $\mathcal{E}$ Others:

23. Online recruitment websites can be trusted with your personal information:

\begin{tabular}{|c|c|c|c|c|}
\hline $\begin{array}{l}\text { Strongly } \\
\text { Agree }\end{array}$ & Agree & $\begin{array}{l}\text { Neither Agree } \\
\text { nor Disagree }\end{array}$ & Disagree & $\begin{array}{l}\text { Strongly } \\
\text { Disagree }\end{array}$ \\
\hline 5 & 4 & 3 & 2 & 1 \\
\hline
\end{tabular}

24. Internet connection and browsing cost in your locality-

\begin{tabular}{|l|l|l|l|l|}
\hline $\begin{array}{l}\text { Very } \\
\text { Satisfactory }\end{array}$ & Satisfactory & $\begin{array}{l}\text { Neither Satisfactory } \\
\text { nor Dissatisfactory }\end{array}$ & Dissatisfactory & $\begin{array}{l}\text { Very } \\
\text { Dissatisfactory }\end{array}$ \\
\hline 5 & 4 & 3 & 2 & 1 \\
\hline
\end{tabular}

25. Which problem, do you think is the worst in case of job searching through internet?

$\square$ Response rate is comparatively low $\quad \square$ Time consuming $\quad \square$ Costly 